\title{
A Thermal Degradation (Thermolysis) Study of Rotenone Extracted from Derris elliptica Roots Using Reverse-Phase High Performance Liquid Chromatography (RP-HPLC)
}

(Kajian Degradasi Terma (Termolisis) bagi Rotenon dalam Cecair Ekstrak Mentah Pekat (CLCE) Diekstrak daripada Akar Derris elliptica Menggunakan Fasa Keterbalikan Cecair Kromatografi Berprestasi Tinggi (HPLC))

\author{
SAIFUL IRWAN ZUBAIRI*, MOHAMAD RoJI SARMIDI \& RAMLAN ABDUL AZIZ
}

\section{ABSTRACT}

Bio-pesticides are becoming increasingly important as pest management tools in various cropping systems in the tropics essentially to remedy problems associated with the indiscriminate use of 'hard' and non-environmental friendly inorganic pesticide. In these past few decades, many bio-pesticidal products, both microbial-based (bacteria, fungi, microsprodia, entomopathogenic nematodes and viruses) and plant-based botanicals (rotenone and azadiracthin) have been studied for their use against insect pests in the tropics. In this study, the effects of the concentration process with respect to the yield of rotenone $(\mathrm{mg})$ and its concentration $(\mathrm{mg} / \mathrm{mL})$ are presented extensively. The raw plants were collected from Kota Johor Lama, Johor and sorted to obtain the roots and stems. Only the roots and stems were utilized as raw materials of the extraction process. The rotenone from roots and stems was extracted using the normal soaking extraction (NSE) at 28 to $30^{\circ} \mathrm{C}$ with $95 \%(\mathrm{v} / \mathrm{v})$ of acetone as a solvent and the solvent-to-solid ratio of $10 \mathrm{~mL} / \mathrm{g}$. The extraction was carried out for $24 \mathrm{~h}$. Next, the liquid crude extract was concentrated using the rotary evaporator at $50^{\circ} \mathrm{C}$ and $80 \mathrm{mbar}$ of vacuum pressure to remove approximately $90 \%$ of solvent. The fractions of the liquid crude extract were collected $(15 \mathrm{~min} / \mathrm{mL} /$ fraction), diluted (1/100 with acetone) and cleaned up (to remove any fine debris) prior to determination of rotenone content $(\mathrm{mg})$ and concentration $(\mathrm{mg} / \mathrm{mL})$ by using the reverse-phase high performance liquid chromatography $(R P-H P L C)$. Finally, the results showed that there was a significant effect of thermal degradation or dissipation of rotenone content at higher operating temperature (greater than $40^{\circ} \mathrm{C}$ ) with a rapid rotenone reduction for the first 15 min of exposure. The possibilities for better exploitation and identification of the effective operating parameters based on the above mentioned results will be perhaps discussed in the future.

Keywords: Concentrated liquid crude extract; Derris elliptica; rotenone; thermal degradation

\section{ABSTRAK}

Bio-pestisid pada masa ini sedang mengalami peningkatan yang sangat penting sebagai kaedah mengawal makhluk perosak dalam variasi sistem tanaman tropika terutamanya sebagai jalan untuk mengatasi masalah yang berkaitan dengan penyalahgunaan pestisid bahan bukan organik berat yang tidak mesra alam. Dalam beberapa dekad yang lalu, banyak produk bio-pestisid, kedua-duanya bagi basis mikrob (bakteria, kulat, mikrosprodia, entomopatogenik nematod dan virus) dan bahan botani berasaskan tumbuhan (rotenon dan azadiraktin) telah dikaji berkesan untuk kegunaan serangga perosak dalam iklim tropika. Dalam kajian ini, kesan daripada proses pemekatan terhadap keberhasilan rotenon $(\mathrm{mg})$ dan kepekatannya $(\mathrm{mg} / \mathrm{mL})$ telah dikaji secara menyeluruh. Sumber pokok mentah dikumpulkan dari Kota Johor Lama, Johor dan diasingkan untuk pengumpulan akar dan batang. Hanya akar dan batang sahaja digunakan sebagai sumber bahan mentah untuk proses pengekstrakan. Rotenon daripada bahagian akar dan batang diekstrak menggunakan pengekstrakan celuran norma pada suhu bilik iaitu 28 to $30^{\circ} \mathrm{C}$ dengan $95 \%$ (v/v) aseton sebagai pelarut dan nisbah pelarut-kepada-pepejal bagi proses pengekstrakkan adalah $10 \mathrm{~mL} / \mathrm{g}$. Proses pengekstrakan dijalankan selama 1440 min. Seterusnya, cecair ekstrak mentah dipekatkan menggunakan alat penyejatan berpusing pada suhu $50^{\circ} \mathrm{C}$ dan tekanan vakum 80 mbar untuk mengeluarkan pelarut aseton sebanyak lebih kurang $90 \%$. Fraksi cecair ekstrak mentah dikumpulkan (15 min/mL/fraksi), dicairkan (1/100 dengan aseton) dan ditapis (untuk membuang sebarang habuk halus) sebelum proses analisis kandungan rotenon $(\mathrm{mg})$ dan kepekatannya $(\mathrm{mg} / \mathrm{mL})$ menggunakan fasa terbalik cecair kromatografi berprestasi tinggi (HPLC). Akhirnya, keputusan uji kaji menunjukkan bahawa terdapat kesan signifikan degradasi terma terhadap kandungan rotenon pada suhu operasi tinggi (melebihi $40^{\circ} \mathrm{C}$ ) dengan kadar pengurangan pantas rotenon pada 15 min pertama operasi. Kebarangkalian untuk mengkaji dan mengenal pasti parameter operasi yang lebih effektif berdasarkan kepada keputusan uji kaji ini akan dibincangkan kelak.

Kata kunci: Cecair ekstrak mentah pekat; degradasi terma; Derris elliptica; rotenon 


\section{INTRODUCTION}

Derris elliptica or 'Tuba' as it is known locally is an insecticidal plant in Malaysia that has been used for the purpose of bio-pesticide production. 'Tuba' plant is a kind of woody creeper plant and a climber. It needs at least $75 \%$ soil moisture content and the surround temperature should be 25 to $30^{\circ} \mathrm{C}$ to obtain high content of rotenone during its development. A calm area with low acidity of soil content will enhance the production of rotenone (Grinda \& Gueyne 1986). 'Tuba' is a member of the Leguminosae, Fabaceae family, which comprises of 200 genera and 68 species including 21 species of Tephrosia, 12 of Derris, 12 of Lonchocarpus, 10 of Millettia and several of Mundula (John \& Ron 1944). Three species are found in Malaysia, which are Derris elliptica, Derris malaccensis and Derris uliginosa (Gaby 1986). Derris is a climbing plant in Southeast Asia and its roots contain rotenone which is derived from one of the secondary metabolites in isoflavonoids group (Figure 1). The Amazonian Derris elliptica and Derris malaccensis contain approximately 4 to $5 \%(w / w)$ rotenone while Lonchocarpus utilis and Lonchocarpus urucu contain 8 to $10 \%$ (w/w) rotenone in dried roots (Kole et al. 1992). However, rotenone content in the extracts of Derris elliptica dried roots collected from the state of Johor, Malaysia has less than $1.2 \%(\mathrm{w} / \mathrm{w})$ (Zubairi et al. 2014a). Irrespective of its availability in nature, this strong insecticide is commonly used by the aborigines/natives to paralyze the fish and to kill insects that infested their vegetables and fruits (John \& Ron 1944). There are many uses of these insecticides that have been discovered. In addition to their effectiveness for both piercing-sucking insects, such as aphids and red bugs and chewing insects, especially caterpillars upon plants, they also make excellent dusts for external parasites of animals such as fleas and lice (Grinda \& Gueyne 1986). However, the bio-active constituents (especially rotenone) available in rotenoids resin (Zubairi et al. 2014b, 2014c) are essentially prone to thermal degradation and photochemically unstable (photolysis). The thermal degradation or thermolysis is defined as a chemical decomposition caused by heat/radiation which breaks chemical bonds in the compound (Pielichowski \& Njuguna 2008). The breakdown mechanism starts with the energy absorption to break chemical bonds in pesticide molecules which are in the ranges of 70 to 120 $\mathrm{kcal} \mathrm{mol}^{-1}$. This energy then excites the molecules and produced oxygen reactive species. The radical molecules will starts to cleavage big molecules into smaller inactive molecules (Toshiyuki 2004). Therefore, the toxic principles (especially rotenone) contained inside the rotenoids resin are believed to deteriorate rapidly into smaller molecules of dihydrorotenone (non-toxic substance) and water when exposed to sunlight and air (surrounding temperature: 35 to $40^{\circ} \mathrm{C}$ ) (Cavoski et al. 2007). Any kind of applications using the extracted rotenoids resin such as spray and dusts typically lose their effectiveness within a week after application (Schnick 1974). For that reason, this study was carried out to observe and to identify the effect of rotenone content extracted from Derris elliptica roots and the extent of rotenone dissipation against high operating temperature (greater than $40^{\circ} \mathrm{C}$ ).

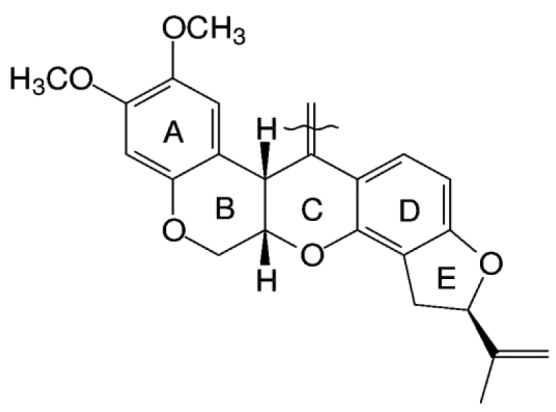

FIGURE 1. Rotenone molecular structures (Kidd \& James 1991; Kole et al. 1992)

\section{MATERIAL AND METHODS}

\section{PLANT COLLECTION}

Derris elliptica was collected in the state of Johor; Kota Johor Lama, Malaysia.

\section{RAW MATERIAL}

An important aspect of the phytochemical processing was the pre-processing of the herbal material prior to the extraction process. The treatment of the herbal material affects the viability of the phytochemical as well as the extraction yield (Grinda \& Gueyne 1986). The procured Derris roots were immediately sent to undergo the cleaning process to remove dirt and soil. The procured Derris roots were kept and dried in an oven overnight at room temperature $\left(28\right.$ to $\left.30^{\circ} \mathrm{C}\right)$ and were sorted to collect the roots and stems. Only roots and stems were utilized. The roots and stems were cut into small pieces prior to grinding.

\section{PREPARATION OF CONCENTRATED LIQUID CRUDE EXTRACT}

The extraction process was carried out by soaking $50 \mathrm{~g}$ of dried roots and stems in $500 \mathrm{~mL}$ of acetone $95 \%(\mathrm{v} / \mathrm{v})$ with a solvent-to-solid ratio of $10 \mathrm{~mL} / \mathrm{g}$ for $24 \mathrm{~h}$ at room temperature $\left(28\right.$ to $\left.30^{\circ} \mathrm{C}\right)$. The liquid crude extracts were filtered through a $15 \mathrm{~cm}$ Whatman filter paper (number 4) directly into $500 \mathrm{~mL}$ beakers after $24 \mathrm{~h}$ of extraction. Next, the liquid crude extract was concentrated using the rotary evaporator (Heidolph-Laborata 4001 ) at $50^{\circ} \mathrm{C}$ and 80 mbar of vacuum pressure. The fractions of the liquid crude extract were collected intervally ( $15 \mathrm{~min} / \mathrm{mL} /$ fraction $)$ and stored in dark vials $(2 \mathrm{~mL})$. 


\section{ANALYSIS OF THE ROTENONE LIQUID CRUDE EXTRACT}

The fractions of the liquid crude extract were subjected to quantitative analysis by using a reverse-phase high performance liquid chromatography (RP-HPLC) with UV (Photodiode Array - PDA) detection at $294 \mathrm{~nm}$ to determine the rotenone content and its concentration. Table 1 shows the operating conditions of reversed-phase HPLC isocratic system. The analysis of the extract solutions was carried out by using the external standard method (Rotenone PESTANAL $^{\circledR}$, analytical grade, $96.2 \%$ - Sigma-Aldrich ${ }^{\text {тм }}$ as an external standard solution). Table 2 shows the calculation of rotenone yield and actual concentration using RP-HPLC external standard method. The Waters ${ }^{\mathrm{TM}}$ Corp. (C18) liquid chromatography stainless steel column with particle size of $10 \mu \mathrm{m}(3.9 \mathrm{~mm}$ I.D $\times 150 \mathrm{~mm}$ length $)$ was utilized in the analysis. For the preparation of rotenone standard solution, about $20 \mathrm{mg}$ rotenone standard powder (Rotenone PESTANAL ${ }^{\circledR}$, analytical grade, $96.2 \%$ - SigmaAldrich $^{\mathrm{TM}}$ ) was weighed and put into $125 \mathrm{~mL}$ Erlenmeyer glass flask. The standard powder was dissolved with $50 \mathrm{~mL}$ of analytical grade of acetonitrile; $99.9 \%$ (v/v) acetonitrile on a Gyratory shaker for $10 \mathrm{~min}$. After shaking, the standard solution was filtered through a $15 \mathrm{~cm}$ Whatman filter paper (number 2) directly into $50 \mathrm{~mL}$ beakers. About $10 \mathrm{~mL}$ of the standard solution was re-filtered through an organic sample clarification kit (Waters ${ }^{\mathrm{TM}}$ Assoc.) containing $0.45 / 0.5 \mu \mathrm{m}$ filters to remove impurities during the preparation of the solution. The isocratic solvent system was implemented throughout the whole analysis using acetonitrile and deionized water with a ratio of 60:40 as a mobile phase and the amplitude unit full scale (AUFS) of the detection was 2 (AOAC Official Method 2000; Rodney \& Alan 1976).

\section{THIN LAYER CHROMATOGRAPHY}

Initially, $1 \mathrm{~g}$ of concentrated liquid crude extract (CLCE) and $0.5 \mathrm{mg}$ of rotenone standard powder (Rotenone PESTANAL ${ }^{\circledR}$, analytical grade, $96.2 \%$ - Sigma-Aldrich ${ }^{\mathrm{TM}}$ ) were vortexed and dissolved with chloroform (analytical grade) for 10 to $15 \mathrm{~min}$. Next, the thin layer chromatography (TLC) was carried out to analyze the presence of rotenone and its thermolysis byproduct constituents in the CLCE. Petroleum ether and ethyl acetate with a ratio of $6: 4$ were used as a mobile phase in the development chamber (Zubairi et al. 2014c). The separation of the bio-active compound was about 30 to $45 \mathrm{~min}$. The markers that appeared onto the TLC silica plate were viewed and illustrated using the ultraviolet (UV) lamp with the wavelength of $254 \mathrm{~nm}$.

\section{STATISTICAL ANALYSIS}

Data was presented as mean \pm standard deviation (SD) of mean. Statistical comparisons were performed using one-way analysis of variance (ANOVA) for detecting significant differences among sample means of the groups, this was followed by Tukey's test (PASW version 17.0 IBM Co.) for multiple comparisons to determine values that were significantly different. A $p<0.05$ was considered statistically significant.

TABLE 1. Parameters of RP-HPLC (Baron \& Freudenthal 1976)

\begin{tabular}{lr}
\hline Parameters & \multicolumn{1}{c}{ Setting } \\
\hline Column temperature $\left({ }^{\circ} \mathrm{C}\right)$ & Ambient \\
Flow rate of separation & $0.4 \mathrm{~mL} / \mathrm{min}$ \\
UV wavelength $(\lambda)$ & $294 \mathrm{~nm}$ \\
Injection volume & $5 \mu \mathrm{L}$ \\
Amplitude unit full scale (AUFS) & 2 \\
\hline
\end{tabular}

TABLE 2. Calculation of rotenone yield and actual concentration using RP-HPLC external standard method

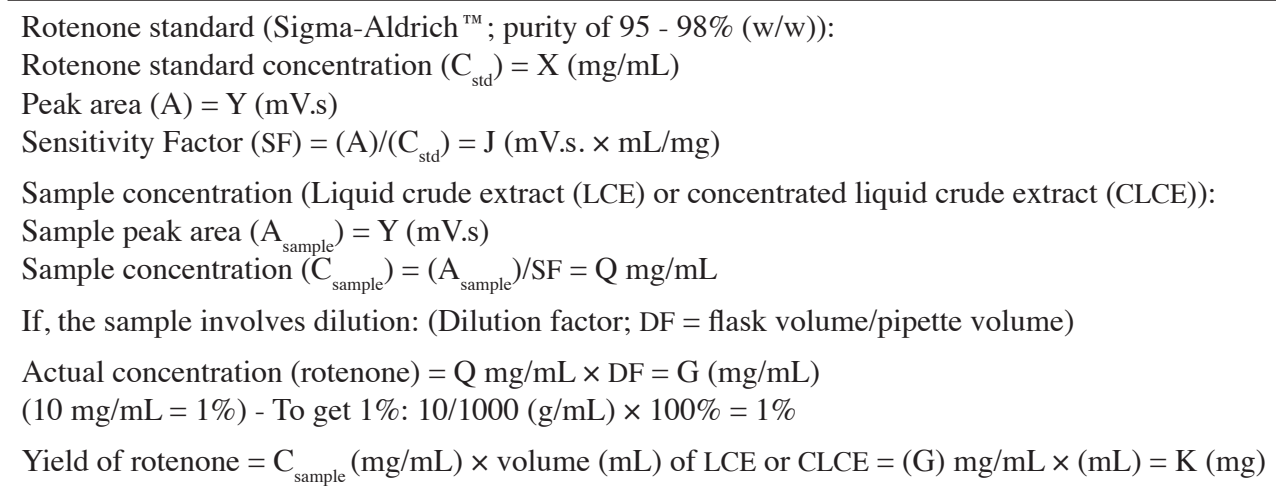




\section{RESULTS AND DISCUSSION}

The main objective of this study was to observe the thermal degradation profile of rotenone when exposed to high operating temperature (greater than $40^{\circ} \mathrm{C}$ ) as rotenone is commonly known as a light (photolysis) and heat (themolysis) sensitive compound. Since there is no study conducted to observe the sensitivity of rotenone extracts taken from Malaysia Derris spp. on the thermolysis behaviours, this study was employed. Figure 2 shows that there was a significant reduction of rotenone $(\mathrm{mg})$ for the first $15 \mathrm{~min}$ of the concentration process $(p<0.05)$. Thus, it appears that rotenone is strongly affected by the temperature greater than $40^{\circ} \mathrm{C}$. The initial concentration of the liquid crude extract was observed to be $41.75 \pm 3.2 \mathrm{mg} / \mathrm{mL}$ (rotenone content: $35,072 \pm 155 \mathrm{mg}$ ). As the concentration time increased, the amount of rotenone was reduced tremendously by $90 \pm 2.5 \%(\mathrm{w} / \mathrm{w})$ for the first $15 \mathrm{~min}$ of the process and the amount of rotenone remained constant until $105 \mathrm{~min}$ where the highest concentration occurred $(122 \pm 5.8 \mathrm{mg} /$ $\mathrm{mL}: 1,108 \pm 146 \mathrm{mg}$ of rotenone) (Figure 3 ). The reduction of rotenone content in the extract was in line with Grinda and Gueyne's (1986) findings whereby the rotenone content could only be retained up to $14 \%(\mathrm{w} / \mathrm{w})$ with the existence of operating temperature up to $45^{\circ} \mathrm{C}$ for half an hour. Meanwhile, the half-life $\left(\mathrm{t}_{1 / 2}\right)$ of rotenone under photolysis is predicted to be approximately $3 \frac{1}{2} \mathrm{~h}$ when exposed to bright sunlight (approximately 30 to $40^{\circ} \mathrm{C}$ ) (Grinda \& Gueyne 1986; Pagan et al. 1949). For that

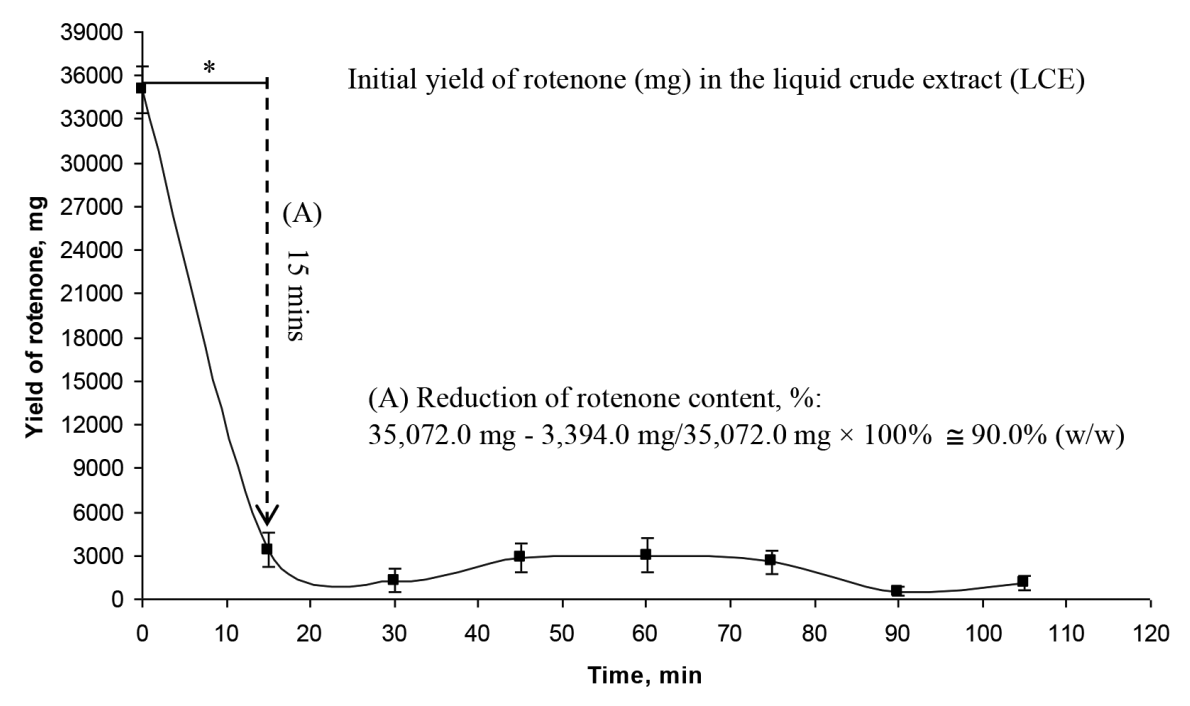

FIGURE 2. The profile of rotenone degradation $(\mathrm{mg})$ during the concentration process at $50^{\circ} \mathrm{C}$ and $80 \times 10^{-3}$ bar. Results shown were means \pm S.D. in triplicate $(n=3)$. $\left(^{*}\right) p<0.05$ for absorbance decreased/increased as compared to that of the previous time

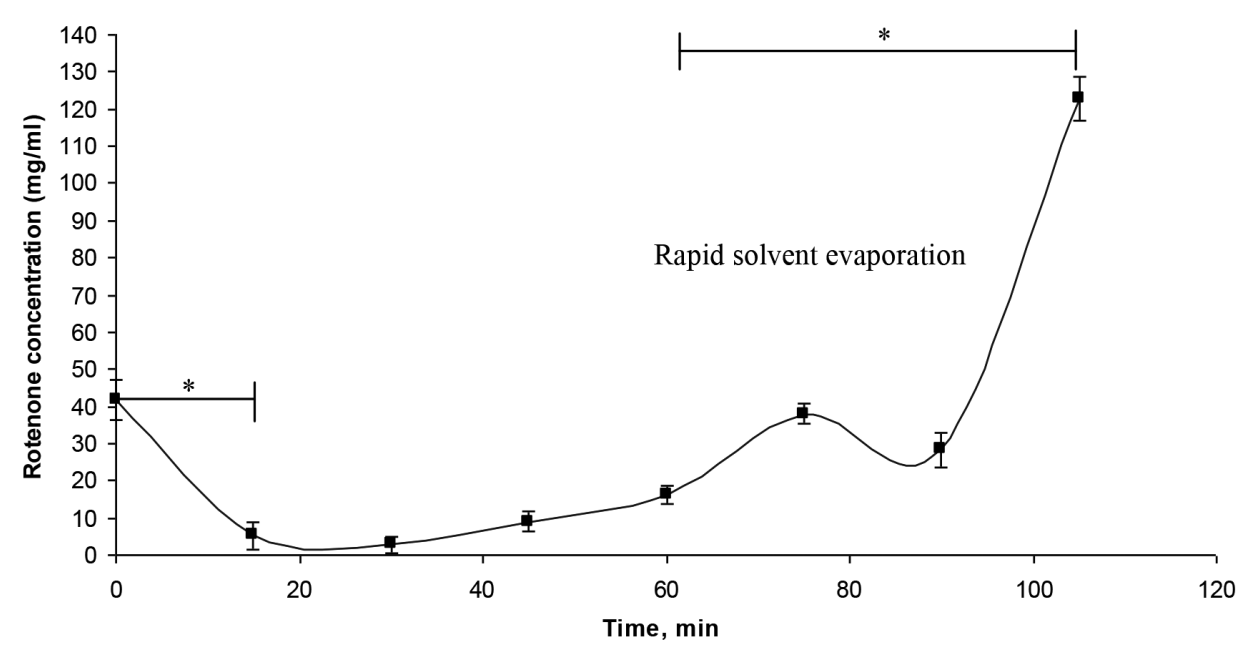

FIGURE 3 . The profile of rotenone concentration $(\mathrm{mg} / \mathrm{mL})$ during the concentration process at $50^{\circ} \mathrm{C} \& 80 \times 10^{-3}$ bar. Results shown were means \pm S.D. in triplicate $(n=3) .(*) p<0.05$ for absorbance decreased/increased as compared to that of the previous time 
reason, the use of high operating temperature during the extraction, concentration and formulation process must be avoided so that the sustainability of rotenone in the extract could be optimized irrespective of any type of Derris spp. and location of the plant collected.

Although most of the plant secondary metabolites are thermal resistance, this finding has proven that rotenone is one of the metabolites that is very sensitive to prolong heat exposure and it needs to be extracted and operated below $40^{\circ} \mathrm{C}$. The reason behind this is that when rotenone is exposed to light, air and heat, it decomposes into dihydrorotenone and water resulting in non-insecticidal bio-active compounds (Cavoski et al. 2007; Schnick 1974). Another study by Cheng et al. (1972), using photo-degradation, identified that rotenone decomposed to at least 20 degradation products, most of which were rotenoids (rotenone and its derivatives). They reported that only one product, $6 a \beta, 12 \alpha \beta$-rotenolone, was toxic. The fact that the other 19 degradation products are not toxic is the reason why rotenone is justifiable to be used as an environmental friendly bio-pesticide. For that reason, thin layer chromatography was carried out to identify the availability of the rotenone thermolysis byproducts in the concentrated liquid crude extract (CLCE). The numbers of bio-active constituent spots in the liquid crude extract and rotenone standard were 6 and 3 , respectively. Meanwhile, for the CLCE at $105 \mathrm{~min}$ of concentration time, there were around 10 to 12 spots observed. The additional 6 spots were believed to be rotenone thermolysis byproducts of unknown phytochemical names (Figure 4).

\section{CONCLUSION}

After some extensive studies have been done, there are several conclusions that can be drawn. First, rotenone is strongly affected by the operating temperature greater than $40^{\circ} \mathrm{C}$ irrespective of any location of Derris spp. collected (in this study, the roots were collected from the state of Johor, Malaysia). Temperature greater than $40^{\circ} \mathrm{C}$ will result in dissipation of rotenone into non-toxic compounds. The appearances of several unknown spots (TLC analysis) proved that the existence of rotenone thermolysis byproducts in the concentrated extract were undeniable. Second, to extract the rotenone effectively, the extraction process coupled with sonication is recommended as it ruptures plant cell wall easily and increases the rate of diffusivity into bulk volume of solvent. In fact, it should be done at certain temperature (below than $40^{\circ} \mathrm{C}$ ). Although in principle, as the extraction temperature increases; it will increase the rate of extraction by increasing the internal diffusion as well as the mass transfer coefficient values and thus reducing the extraction time. However, it should be noted that increasing the temperature beyond certain values will lead to a decrease in isoflavonoid compounds' yield due to the high susceptibility of the isoflavonoid to high temperature.

\section{ACKNOWLEDGEMENTS}

All thanks are due to the Ministry of Science, Technology \& Environment (MOSTE), Malaysia for the financial assistance under RM8 IRPA 04-01-06-SF0077 and the Universiti Teknologi Malaysia (UTM) for the research facilities provided.

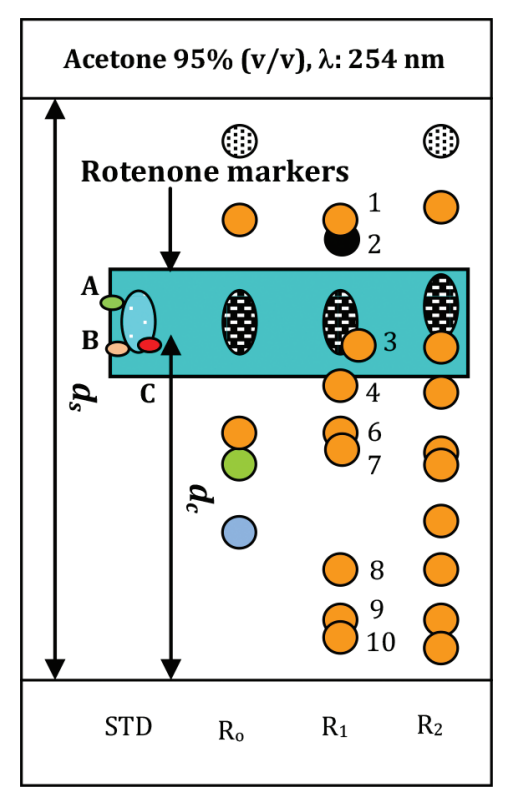

FIGURE 4. The presence of rotenone on the thin layer chromatography (TLC) silica plate. Petroleum ether and ethyl acetate with a ratio of 6:4 was used as a mobile phase. The markers were visualized under UV light with wavelength $(\lambda)$ of $254 \mathrm{~nm}\left(d_{s}=\right.$ migration distance of solvent front; $d_{c}=$ migration distance of substance; $\mathrm{STD}=$ rotenone standard). $\mathrm{R}_{0}$ - Liquid crude extract; $\mathrm{R}_{1} \& \mathrm{R}_{2}$ - Concentrated liquid crude extract at 105 min of concentration time 


\section{REFERENCES}

AOAC. 2000. Official Method 983.06, Rotenone in Pesticide Formulations. Liquid Chromatographic Method. First Action 1983 and Final Action 1991. AOAC Official Method of Analysis.

Baron, L.R. \& Freudenthal, I.R. 1976. Separation of rotenoids by high pressure liquid chromatography. Journal of Chromatography 134: 207-209.

Cavoski, I., Caboni, P., Sarais, G., Cabras, P. \& Miano, T. 2007. Photodegradation of rotenone in soils under environmental conditions. J. Agric. Food Chem. 55(17): 7069-7074.

Cheng, H.M., Yamamoto, J.E. \& Casida 1972. Rotenone photodecomposition. Journal of Agricultural Food. Chem. 20(4): 850-856.

Gaby, S. 1986. Natural crop protection in the tropics - DERRIS: Derris elliptica, D. Malaccensis, D. uliginosa. Weikersheim: Margraf Publishers GmbH Scientific Books.

Grinda, F. \& Gueyne, J. 1986. Extraction of insecticides from plants. USPTO Patent Full -Text and Image Database, Saphyr S.A.R.L. (France) (U.S Patent: 4,698,222).

John, R.A. \& Ron, R.K. 1944. Insect Control. Jour. Econ. Ento. 37: 400-408

Kidd, H. \& James, D.R. 1991. The Agrochemicals Handbook. 3rd ed. Royal Society of Chemistry Information Services. Cambridge: United Kingdom. pp: 2-13.

Kole, R.K., Satpathi, C., Chowdhury, A. \& Ghosh, M.R. 1992. Isolation of amorphalone, a potent rotenoid insecticide from Tephrosia candida. J. Agri. Food Chem. 40: 1208-1210.

Pagan, C., Richard, R.H. \& Loustalot, A.J. 1949. The effect of sun, shade and oven-drying on the toxicological and chemical values of Derris root. Journal of Agricultural Research 78: 11.

Pielichowski, K. \& Njuguna, J. 2008. Thermal Degradation of Polymeric Materials. Shrewsbury: Smithers Rapra Press.

Rodney, B. \& Alan, H. 1976. Determination of rotenone in pesticide formulations and the separations of six rotenoids by reversed-phase high performance liquid chromatography. Journal of Chromatography 134(1977): 210-215.
Schnick, R.A. 1974. Review of the literature on the use of rotenone in fisheries. FWS-LR-74/15, NTIS Conc. No. PB235 454/6, Bureau of Sport Fisheries and Wildlife, La Crosse, Wis. Fish Control Lab. 7423:130.

Toshiyuki, K. 2004. Photodegradation of pesticides on plant and soil surfaces. Rev. Environ. Contam. Toxicol. 182: 1-195.

Zubairi, S.I., Sarmidi, M.R. \& Aziz, R.A. 2014a. A study of rotenone from Derris roots of varies location, plant parts and types of solvent used. Adv. Environ. Biol. 8(2): 445-449.

Zubairi, S.I., Sarmidi, M.R. \& Aziz, R.A. 2014b. Identification of bio-active constituents from Derris elliptica liquid crude extract using vacuum liquid chromatography. Adv. Environ. Biol. 8(2): 437-440.

Zubairi, S.I., Sarmidi, M.R. \& Aziz, R.A. 2014c. Precipitation of rotenoids resin extracted from Derris elliptica roots by means of clarifying agents. Adv. Environ. Biol. 8(2): 441-444.

Saiful Irwan Zubairi*

School of Chemical Sciences \& Food Technology

Faculty of Science \& Technology

Universiti Kebangsaan Malaysia

43600 Bangi, Selangor Darul Ehsan

Malaysia

Mohamad Roji Sarmidi \& Ramlan Abdul Aziz

Institute of Bioproduct Development

Universiti Teknologi Malaysia

81310 Skudai, Johor Darul Takzim

Malaysia

*Corresponding author; email: saiful-z@ukm.edu.my

Received: 20 August 2013

Accepted: 2 July 2014 